Rhode Island College

Digital Commons @ RIC

Master's Theses, Dissertations, Graduate Research and Major Papers Overview

4-27-2020

\title{
The Evolution of the Spinster: Austen and Woolf's Single Women Characters
}

Naomi Stewart

Follow this and additional works at: https://digitalcommons.ric.edu/etd

Part of the English Language and Literature Commons, Other Feminist, Gender, and Sexuality Studies Commons, and the Women's Studies Commons

\section{Recommended Citation}

Stewart, Naomi, "The Evolution of the Spinster: Austen and Woolf's Single Women Characters" (2020). Master's Theses, Dissertations, Graduate Research and Major Papers Overview. 326.

https://digitalcommons.ric.edu/etd/326

This Thesis is brought to you for free and open access by Digital Commons @ RIC. It has been accepted for inclusion in Master's Theses, Dissertations, Graduate Research and Major Papers Overview by an authorized administrator of Digital Commons @ RIC. For more information, please contact digitalcommons@ric.edu. 
THE EVOLUTION OF THE SPINSTER:

\title{
AUSTEN AND WOOLF'S SINGLE WOMEN CHARACTERS
}

By Naomi Stewart

\author{
A Thesis Submitted in Partial Fulfillment \\ of the Requirements for the Master of English in \\ The Department of English \\ The School of Arts and Science \\ Rhode Island College
}




\section{Introduction}

In Jane Austen's novel Emma, the sentiment, ““[a] single woman, with a very narrow income, must be a ridiculous, disagreeable, old maid! the proper sport of boys and girls; but a single woman, of good fortune, is always respectable, and maybe as sensible and pleasant as anybody else"" (73), epitomizes the view of women in the eighteenth century. Women were portrayed as fragile and helpless; their only job was to take care of the family. Impoverished women who never marry were characterized as bitter and lonely, while affluent women remained vibrant and sociable. Economic independence could save single women from the worst ridicule, but members of all social classes view spinsters as outcasts for not conforming to societal and gender norms. Austen utilizes these ideas of spinsterhood to expose the unrealistic expectations placed on women of her time. Every woman was expected to marry a man and become a mother. These traditional gender roles show how filling the role of wife and mother limits women to only working in the household. Women who stepped outside of these prescribed gender roles were peculiar and overlooked.

Feminist criticism is broadly defined as "the ways in which literature (and other cultural productions) reinforces or undermines the economic, political, social, and psychological oppression of women" (Tyson 83). Works written by male authors in the nineteenth century often portray their female characters as severely dependent on men. Women writers of that time often reflected the constricted life of a woman in their novels. These characters show how women had no access to an education beyond what they learned from their mother; only men were allowed an education. Therefore, there was no other role for a woman than wife and mother. Women writers understood this discrepancy and sought change by writing women 
characters who could think for themselves. They started to transition away from the idea of womanhood as simply wife and mother. Austen is often the center of the conversation about womanhood in the eighteenth and nineteenth centuries. Even though her heroines marry the men they love by the close of the novel, the journey to that happy ending is not always straight forward.

In the eighteenth and nineteenth centuries, unmarried women who were well into their twenties were considered "old maids" and past their "bloom." Single women have been called many different names: spinster, old maid, and "redundant woman" are most common. A prevalent argument that circulated in the eighteenth and nineteenth centuries, pointed out by Breanna Neubaure in her article "This Old Maid: Jane Austen and Her S(p)i(n)sters," states that "ladies who heartbreakingly must, as W.R. Rathbone in his 1869 article 'Why Are Women Redundant?' says, 'lead an independent and incomplete existence of their own' while 'their hearts [wither] because they have... none to cherish, love, and obey"' (124-125) relays a common attitude. In a time when a woman's sphere of influence was only the home life, to not marry and create a family was considered odd and unwomanly. Austen goes against social norms and portrays single gentry-class women as strong and independent. Those social norms implied that single women from lower classes who did not marry were to find work and support themselves, while women from the upper classes relied on their fathers and brothers to support them. The single woman from the upper-class would be put to work in the house, becoming a glorified maid. She would still attend family gatherings and be a part of the family, but the everyday life was spent helping run the household. The spinster character in the British novel reflects the struggle unmarried women of the eighteenth and nineteenth centuries endured. As 
time progresses, the spinster character remains, but her struggle comes to include her sexuality being questioned as well.

Within the novel, spinsters can be seen in various roles. One role the spinster takes is the old maid. This character has never married and serves as a warning to the younger generation of women in the novel. The old maid character is there to either guide young women into the proper marriage or portrays what the young women will become if they do not marry. A second role is the spinster-aunt, a woman who has the qualities of a mother but no children of her own. The aunt character can be used as a warning to her niece, or the aunt could become a mother figure for an orphaned young woman. Whatever role the spinster takes, she is labeled an outcast because she does not conform to societal norms.

Jane Austen's novels convey the struggle unmarried women endured, but they also show women having more of a choice in their husbands than was the tradition for woman of their class at the time. The spinster character was not limited to Austen's time; this figure can also be seen in works of Virginia Woolf. From Austen's time to Woolf's, conditions for women changed dramatically, but the spinster character remains as a warning instrument. Nevertheless, in Woolf's novels, the spinster also represents the advances women have made in the world. My thesis will explore the topic of spinsterhood within Pride and Prejudice and Persuasion by Jane Austen. I will also show how spinsterhood has adapted through time by looking at Mrs. Dalloway and To the Lighthouse by Virginia Woolf. Within these novels, spinsterhood evolves as a form of empowerment for future generations of women. By the twentieth century, women were gaining more rights and the ability to make their own choices when it came to marriage. By altering the traditional marriage plot, Austen sets the stage for Woolf's transformation of the spinster character in To the Lighthouse. 
It is thought that the increase of spinsters in the eighteenth and nineteenth centuries started with the passing of the Marriage Act in 1753. Most commonly known as Lord Hardwicke's Marriage Act, this law stated that anyone under the age of 21 was not to marry without parental consent. Vlasta Vranjes, in the article "Jane Austen, Lord Hardwicke's Marriage Act, and the National Courtship Plot," explains this law:

By departing from canon law and requiring that marriages of those younger than twentyone be approved by parents or guardians, the Act for Better Preventing of Clandestine Marriages (popularly known as Lord Hardwicke's Marriage Act) ensured—or so its critics argued both in 1753 and in the years that preceded its repeal in 1823-that wealthy or titled women could not choose their spouses freely until after they had outgrown a susceptibility to romantic love, which threatened the landed interests, and grew to prefer socially ambitious matches that strengthened those interests. (200)

By limiting who young people from the upper classes marry, the older generation was able to keep the lower classes from gaining status by marriage. At the time, marriage was a business transaction between wealthy families. In Austen's works there are numerous examples of older generations encouraging their children to marry someone who had money. It did not matter if their son or daughter were in love with someone else; the parents had the final say in who the child was to marry. The Marriage Act caused young men and women to elope and leave their family's money, forcing the couple to fend for themselves. Although the Marriage Act was repealed in 1823 , wealthy families continued to limit with whom their children socialized.

In the years that followed this act, a subgenre of the novel emerged with what is called the marriage plot. These novels served as examples for women on the proper way to choose a husband. The plot of this subgenre consists of the heroine's progress from wanting a marriage 
based on love and affection to choosing a husband who has financial stability. Austen takes this marriage plot, explores its inner workings, and transforms it. In Pride and Prejudice, for example, Elizabeth Bennet at first overlooks Mr. Darcy and instead pursues George Wickham until she overcomes her prejudices. Elizabeth initially wants the handsome man with whom she thought she was in love. As the novel progresses, however, Darcy and Elizabeth form a friendship through their disagreements. As a result, they discover themselves and that being together is what makes them happy, and that trumps all financial considerations. Though Elizabeth does indeed marry a wealthy man, Austen stresses that their marriage is grounded on love, not economic interests. Austen reverses these ideas in Persuasion. Anne Elliot meets the love of her life, Frederick Wentworth, at a young age, but she is guided away from marrying him because he is from a lower class. She is forced to learn at a young age that marriage is about prosperity, not love. She then turns down suitors in hopes that Wentworth will return single and she will get a second chance at love. Her journey throughout the novel is an example of why some women chose to become spinsters. By using this subgenre to create women characters who make their own decisions, Austen shifts the idea of marriage away from a business transaction and shows women having the strength to decide what is best for themselves.

William H. Magee, in his article "Instrument of Growth: The Courtship and Marriage Plot in Jane Austen's Novels," explains how Austen took the marriage plot and made it her own. He writes:

The courtship and marriage convention of the novel of manners provided early British novelists with the necessary framework for their art of story-telling. It had two important attractions. It concentrated on the central concern of family status in their patriarchal society, and it created a self-contained world of art with an optimistic ending suited to 
their concept of human progress. When centered on a hero, it showed a young man committing his domestic life to a young woman of appropriate class standing and fortune. When centered on a heroine, as in Jane Austen's novels, it featured a young woman entering society in search of a husband to provide her with virtually the only career then open to a woman - that is, marriage. (198) Applying this thought to Pride and Prejudice and Persuasion, the shift away from tradition becomes clear. By creating characters who view marriage as a partnership, Austen effectively takes the idea of marriage into another arena. Elizabeth and Darcy have a healthy, loving relationship, as do Anne and Wentworth. Marriages that reflect traditional values within these novels are often shown as strained; the couple does not truly love one another. Austen begins to transition away from tradition by creating marriages based on a solid, affectionate relationship. Austen's novels provide a range of relationships to examine. The female characters in each novel have strong reasoning for their actions. Some marry because society tells them to, while others marry for love. For some, marriage is their only option out of a bad financial situation, and some do not marry at all. Family and society play a large part in women's adventures in the marriage market. In "The Marriage Law of Jane Austen's World,” Martha Bailey points out that when women in the nineteenth century marry, they essentially lose their former identities. The man took over everything the woman had, and her life merged with her new husband. She would no longer be "Mary," she would become "Mrs. Smith." The woman also took on the role of wife and mother, the only identity available to a woman at the time. If a woman remained unmarried, she became a burden to the family and was treated like a maid. Spinsters and old maids were mistreated in novels written by men in the nineteenth century. In 
"The Old Maid, or 'to grow old, and be poor, and laughed at,"” Jean B. Kern points out that spinsters often became caricatures in these novels. She explains:

As men increasingly took over former female occupations... these single women were left with no respectable role. Fettered by their economic dependence, their frustrated sexuality, and their inability to translate individual talent into a public role in their society, they soon appeared in men's novels as sex-starved, frustrated, and disagreeable stereotypes described by Defoe as 'a set of despicable character called Old Maids.' (201) Austen sought to change the way spinsters were portrayed. By writing spinster characters who were not "sex-starved" or "frustrated," Austen showed the spinster as a normal woman who has simply decided not to marry.

In Persuasion, Anne Elliot is an example of a different kind of spinster. She places herself in the role of a spinster-aunt because her dreams of marriage are in the past. Even though she has had other opportunities to marry, she chooses to remain single because she will never love anyone the way she loves Wentworth. Her role of spinster-aunt is different from a regular spinster role. In the case of Anne, her role is that of a surrogate mother to her nephews. She is often shown helping her sister with the children and even uses them as an excuse to stay behind and not attend a dinner party. She exhibits the qualities of a mother, yet she has no children of her own. Even though Anne is the main character of the novel, she is a background character in her family. She is treated like a maid, helping her sister with her children, playing music while everyone else danced, and jumping into action when someone gets hurt. Her family had taken advantage of her and hampered her initial aspirations of marriage, but in the end, she gets the marriage for which she has waited. 
Not all of Austen's spinster characters have the luxury of waiting to find love. In Pride and Prejudice, Charlotte Lucas is an example of a single woman who does not come from a wealthy family. While Elizabeth can take her time and choose whom she wants to marry, Charlotte has fewer resources and needs someone with financial stability. If she does not marry, she will live a life of poverty, alone. Charlotte's decision to persuade Mr. Collins to marry her shows her desperation. Their marriage is not based on love, but it does have understanding. Charlotte is content with being alone for extended periods of time because her husband is a clergyman. Elizabeth, however, wants an emotional bond and genuine partnership with her future husband. These women all make decisions for themselves. Whether it be remaining single or marrying for security or for love, each woman is shown making the right choice for her.

The problematic view of spinsterhood continues into the twentieth century. As time progressed, women obtained more rights, but the stigma of spinsterhood still lingered. Single women of a certain age were still labeled as outcasts for not conforming to societal norms. In Mrs. Dalloway, Clarissa conforms and marries Richard Dalloway because it is the proper thing to do. In a flashback to her youth, we are shown the summer Clarissa meets Richard. In this flashback, there is also Sally Seton, a woman who shakes Clarissa to her core and changes her feelings for the rest of her life. In "Mrs. Dalloway: the Communion of Saints," Suzette A. Henke states that "female contact has the force of revelation in Clarissa's past, lyrically described in images of erotic ecstasy" (135). The feelings Clarissa had after Sally kissed her have never been matched by Richard. Because of this, Clarissa believes she has failed as a wife. Her feelings for Richard will never equal her feelings for Sally. Her marriage to Richard is not terrible, but it is not perfect either. He gives her the space she needs in a relationship while also taking care of her, almost like a child, by checking on her throughout the day. If Clarissa had not married Richard, 
her choices would have been Peter Walsh or spinsterhood. Clarissa entertained thoughts of being with a woman, but her prudishness and need to conform to social norms prevented her from following through.

The spinsters of Woolf's novels play an essential role. Doris Kilman in Mrs. Dalloway acts as Clarissa's "what if," while Lily Briscoe in To the Lighthouse reflects the future of independent womanhood. Doris is portrayed as having masculine qualities, while Clarissa is more feminine. In "Woolf’s 'Spinsters': The Body and the Blank Page of His/Story," Joanne Wallace explains: "whereas Clarissa invests the ordinary moment and the particularity of daily life with a luminous significance, Doris Kilman attempts to find her significance in the more 'masculine' abstract and logocentric values and systems ---particularly history and religion, both of which, as Woolf makes clear throughout her discursive writings, have silenced or 'veiled' women" (209). Clarissa finds happiness in planning parties and entertaining, while Doris investigates the past to find her meaning. If Clarissa had chosen not to marry Richard, she believes she could have been like Doris, a spinster and outcast, who must tutor the young girls of affluent men because she is not able to teach in a professional setting. Clarissa's daughter, Elizabeth, also connects the two. Both women recognize Elizabeth as the next generation of woman and encourage her to follow her own path while also keeping the past in view. Clarissa shows her how to entertain, while Doris shows her history and religion and new opportunities open to women. Jo-Anne Wallace shows how Doris and Clarissa are connected: "Clarissa, with far greater insight than Doris Kilman evinces, intuitively acknowledges a bond between them: 'for no doubt with another throw of the dice, had the black been uppermost and not the white, she would have loved Miss Kilman!' (17); 'she hated her: she loved her'” (208). Clarissa has a hard time accepting Miss Kilman because Doris reflects what Clarissa would have become if she 
did not marry. Doris' loneliness and neediness frighten Clarissa. At this point Woolf, has not yet come to terms with the spinster choice; she is still ambivalent towards spinsters. To the Lighthouse resolves this ambivalence in the character of Lily Briscoe.

Woolf showcases the new future of womanhood in To the Lighthouse. Lily Briscoe, a single woman trying to support herself through art, shows that a woman does not need to marry to be successful. The relationships portrayed in the novel do not give Lily a compelling reason to marry. In "Where the Spear Plants Grew: the Ramsays' Marriage in To the Lighthouse," Jane Lilienfeld explores the Ramsays' relationship and the traditional view of gender roles. She writes:

Woolf's vision of the Ramsays' marriage is a mature, sharp critical examination not only of her own parents but also of the destruction wreaked by the Victorian social arrangement on human capacities for freedom and growth... this essay will examine in detail Woolf's vision of the Ramsays' marriage, proving that as she celebrates and criticizes it she makes clear the urgency for creating new modes of human love and partnership. (149)

The Ramsays showcase the Victorian ideals of marriage and gender roles, ideals that do not appeal to Lily, making her deliberately turn away from marriage.

The role of the Victorian woman that Lily refuses is to stay home and take care of the household while the man works. Mrs. Ramsay fills the role of "Angel in the House," a passive, selfless woman who caters to others, while encouraging the young women in her life to follow in her footsteps. However, if Lily married, she would have to give up her art and independence. As Lilienfeld observes, “"The ideology of motherhood' is designed to keep women powerless, for the only power they are allowed in patriarchal society is their ambiguous hold on small children" 
(159). Mrs. Ramsay has no authority in her household; having no real education, she is often pitied by the others in the house. In Victorian times, the less a woman knows, the more desirable she becomes and is more dependent on a husband. Lily's ability to create a life for herself without a husband shows progress for women. Lilienfeld explains that "in Lily's moving beyond Mrs Ramsay's mode of behavior we see a major transition in woman's use of the power of selfhood, as the centre of power shifts away from the narrow scope of the home to the outer world of work and self-actualisation. Lily comes to cherish in herself powers different from those that motivate Mrs Ramsay" (164). After Mrs. Ramsay's death, Lily creates a unique way to love and help others.

Like Austen, Woolf explores the roles available to women with her characters Lily Briscoe and Mrs. Ramsay. In The Artist-Figure, Society, and Sexuality in Virginia Woolf's Novels, Ann Ronchetti notes that "by focusing largely upon Lily Briscoe and Mrs. Ramsay... Woolf enables herself to investigate two of the forms of creativity available to women - that of painting... and that of women in their traditional domestic roles as wives, mothers, and social managers" (62). Women today no longer have just one role; society has started to give women a chance to become something other than wife and mother. Lily represents this new role for women of the twentieth century. As Lilienfeld states, "Lily's refusal to marry, and her avoidance of heterosexuality as Mrs Ramsay had envisioned it, are not a failure to be womanly, for being womanly no longer means being defined by one's relation to men or to one's reproductive system" (165). Women can still become mothers and wives, but those who do not are no longer portrayed as failures and outcasts. Woolf and Austen showed spinsters as active participants in society, not as bitter, sex-starved women. Austen paved the way for the emergence of a character like Lily Briscoe by re-inventing the marriage plot and highlighting the importance of woman's 
desire and choice in selecting a husband. Woolf furthers this view by presenting the spinster character as an artist, as a positive female character who creates an independent identity outside the societal norms. 


\section{Pride and Prejudice: Altering the Marriage Plot}

The structure of Pride and Prejudice is that of a marriage plot. This sub genre of novel was popular in the eighteenth and early nineteenth centuries. Women authors utilized the popularity of these novels to make a living writing. Marriage plot novels consisted of two conventions: the lover-mentor and the perfect heroine. Julia Shaffer explains these conventions in her article "Not Subordinate: Empowering Women in the Marriage-Plot— The Novels of Frances Burney, Maria Edgeworth, and Jane Austen." With the second convention, "the heroine need not actually be schooled by her lover but does need [to] recognize that his values and approach to the social world constitute those which she must accept to be considered mature and marriageable" (Shaffer 54). The perfect heroine is rare and portrayed as "moral and willing to act like exemplars and yet are also modest" (Shaffer 56). Shaffer explains how the lover-mentor convention shows a naïve young woman's journey to understanding the world around her. At first, the heroine has unrealistic expectations of romance created by the romance novels she has read. Her lack of experience in the real world is the perfect reason for the lover-mentor to show her how naïve she is and help guide her to maturity. The mentor will show her the error of her ways, and once she realizes them, she gains the right to marry. This guidance removes any notion that a woman could have power over a man and solidifies the "patriarchal ideology of the period, an ideology best characterized as teaching women to view themselves as subordinate to, dependent upon, and at the service of the men in their lives" (Shaffer 51).

The lover-mentor convention shows women as deficient in their knowledge of and conformity with social norms and in need of correction by male figures. Austen saw the injustice of this marriage plot and began writing imperfect female characters who pushed against this tradition. Even though Austen's novels end with marriage, each woman has had a significant role 
in the choice of that marriage. In Pride and Prejudice, the lover-mentor convention is reworked so that both parties teach each other a lesson.

Pride and Prejudice's opening sentence "[I]t is a truth universally acknowledged that a single man in possession of a good fortune must be in want of a wife" (Austen 1), relays to the reader that money is a primary factor in marriage within this novel. Elizabeth Bennet is aware of her financial situation, but she still advocates for marriage based on love and not just money. Her mother, however, has a different frame of mind. Mr. and Mrs. Bennet have five daughters in need of a husband. For these girls, remaining single is not an option. The reason Mrs. Bennet wants all her daughters to marry well is due to primogeniture, the law where the eldest son inherits the family estate if the father dies intestate. Martha Bailey, in "The Marriage Law of Jane Austen's World," explains:

To some extent, the relative poverty of women was the result of legal rules favoring men, in particular eldest sons. If the owner of a family estate--- the family house and lands and income generated by the land--- died intestate, the rule of primogeniture applied: the eldest son inherited the family estate. In the absence of children, or of male children, collateral relatives, usually males, in order of seniority, inherited the estate.

Primogeniture was the rule applied in cases where a landowner died intestate.... The purpose of favoring the eldest son, either by application of the law of primogeniture or by wills or settlements, was to keep family estates intact and free of heavy obligations to support other family members. (1)

The Bennets did not have any sons; the only male heir is a cousin, Mr. Collins. The family could not rely on Mr. Collins being a generous man and helping the girls financially. Therefore, the Bennet sisters need to find wealthy husbands. The law of primogeniture left many young women 
without an income and at the mercy of their male relatives. Women from large families in the landed gentry, like the Bennet girls, understood how important it was to marry a wealthy man. Having this understanding did not stop Elizabeth, however, from wanting more out of her marriage. Austen did not want her characters to simply follow the outdated marriage plot; she had her heroine insist on a romantic connection rather than simply money.

Mr. Collins is set to inherit Mr. Bennet's estate when he passes. Collins wishes to right some wrongs his father had made with Mr. Bennet and intends on marrying one of his daughters so they are not completely left out in the cold. Based solely on the letter he has written to Mr. Bennet, Elizabeth assumes knowledge of his character: “"He must be an oddity, I think,' said she. 'I cannot make him out.-There is something very pompous in his style.-And what can he mean by apologizing for being next in the entail?-We cannot suppose he would help it, if he could.-Can he be a sensible man, sir?"' (Austen 54). In this case, she is right to think him an oddity. Austen explains Mr. Collins as "not a sensible man, and the deficiency of nature had been little assisted by education or society—-the greatest part of his life having been spent under the guidance of an illiterate and miserly father-and though he belonged to one of the universities, he had merely kept the necessary terms, without forming at it any useful acquaintance" (59) and his "very good opinion of himself, of his authority as a clergyman, and his rights as rector, made him altogether a mixture of pride and obsequiousness, self-importance and humility" (69). He is so full of himself that he is sure that Jane will marry him. Hazel Jones in Jane Austen and Marriage summarizes why Collins chooses Jane first: "She was the prettiest and he is confident that he is enough of a catch to stipulate for a 'handsome' partner" (16). When he finds out that Jane could potentially be spoken for, he quickly shifts his attention to Elizabeth. Jones also points out that Collins "allows himself eleven days in which to secure his companion 
for life and expects to expend little energy on courtship" (16). He wants a wife who will be seen and not heard, who will listen to his ramblings and be obedient. His proposal to Elizabeth reveals more of Mr. Collins's character not only to the reader, but to Elizabeth as well. His proposal makes himself out to be a martyr. He says he could choose a woman from his own neighborhood but instead decides to marry one of the Bennets, believing the girls would undoubtedly accept him. His proposal was so well rehearsed that Elizabeth did not have a chance to stop it and reject him. When Elizabeth finally has a chance to speak and give her refusal, he waves it off by saying, "it is usual with young ladies to reject the addresses of the man who they secretly mean to accept, when he first applies for their favour; and that sometimes the refusal is repeated a second or even third time. I am therefore by no means discouraged by what you have just said, and shall hope to lead you to the altar ere long" (Austen 93). His notions of women have come from conduct books written by Rev. James Fordyce, who thought women traditionally rejected the first proposal out of modesty. Collins reads aloud to the girls from Fordyce's book Sermons to Young Women after their first dinner together. By having Collins read from Fordyce, Austen places his views of courtship in the past, views that Austen considered no longer legitimate. Elizabeth's refusal of Mr. Collins and his outdated views of women supports her ideal that marriage should be about love, not just money.

To contrast with Elizabeth and her choices, Austen creates Charlotte Lucas. Charlotte is "a sensible, intelligent young woman, about twenty-seven, [and] was Elizabeth's intimate friend" (14). Coming from a large family like the Bennets, Charlotte knows she needs to marry well. Being twenty-seven, Charlotte is considered past her bloom and on her way to spinsterhood. Having brothers means that if she never marries, they would have to take care of her financially. Charlotte does not have a lot of options when it comes to finding a husband. When she finds out 
that Elizabeth has rejected Mr. Collins's proposal, she steps in and takes him off her hands. Jones explains, "For the sake of a home of her own, Charlotte Lucas makes a bid for Mr Collins as early as Netherfield Ball, when she 'goodnaturedly' relieves Elizabeth of his tedious conversation" (17). Charlotte sits for days listening to Mr. Collins, and after two days, her hard work pays off, securing herself a husband. Her family is very much excited about the union. Austen explains, "The whole family in short were properly overjoyed on the occasion. The younger girls formed hopes of coming out a year or two sooner than they might otherwise have done; and the boys were relieved from their apprehension of Charlotte's dying an old maid" (107). Her brothers are also relieved because they will not have to support her. Being able to secure Mr. Collins gives her and her family a comfortable life, even if the marriage is loveless. Charlotte and Mr. Collins represent the outdated view of marriage from which Elizabeth is moving away.

Charlotte did not find Mr. Collins attractive or good company; she only saw a man who could give her a comfortable life. On the subject of the marriage, Charlotte has these thoughts: "Her reflections were in general satisfactory. Mr. Collins to be sure was neither sensible nor agreeable; his society was irksome, and his attachment to her must be imaginary. But still he would be her husband" (Austen 107). Elizabeth is surprised when she finds out they are engaged; she thought her friend's view of marriage was in line with her own. Charlotte, however, believes that "Happiness in marriage is entirely a matter of chance" (Austen 18). While Elizabeth is baffled by her friend's choice in partner, Charlotte defends her decision: 'you must be surprised, very much surprised — so lately as Mr. Collins was wishing to marry you. But when you have had time to think it over, I hope you will be satisfied with what I have done. I am not a romantic, you know. I never was. I ask only a comfortable 
home; and considering Mr. Collins's character, connections, and situation in life, I am convinced that my chance of happiness with him is as fair as most people can boast on entering the marriage state' (109).

Melina Moe, in the article "Charlotte and Elizabeth: Multiple Maternities in Jane Austen's Pride and Prejudice," reflects on the marriage of Charlotte and Mr. Collins: "Charlotte's marriage, as the first of four in Pride and Prejudice, represents past norms whose modern irrelevance is made apparent though the progress of the novel toward a culmination in two affective, consensual unions" (1076). Charlotte is a rational character; she knows if she does not marry, she will become a spinster. Instead of potentially being pitied by her friends and relying on her younger brothers for financial stability, Charlotte has decided to marry and is content with her future. Julia Prewitt Brown, in Jane Austen's Novels, sums up Charlotte's marriage as “not only a 'preservative from want' but a preservative from intelligence, gaiety, and love, an embalmed safety from possibility and the requirement of morality and hope" (76). For Charlotte, being married to someone like Mr. Collins and having a comfortable life is a much better fate than being a spinster. Austen emphasizes that this is a choice for Charlotte that she makes willingly.

By using the lover-mentor convention in Pride and Prejudice, Austen shows Elizabeth's transformation. At the start of the novel, Elizabeth has a lot of the same qualities as her father-a playful disposition and a satiric wit, while she is also quick to ignore the good qualities in others. While talking with her elder sister Jane, Austen shows Elizabeth's perceptiveness as well as her prejudice. This interaction between sisters occurs after they have just met Mr. Bingley and his group, consisting of two of his sisters, one of their husbands, and Mr. Darcy. While Jane is smitten with the group, Elizabeth has other feelings. Even though she has only interacted with the group once, she has judged the women as "in fact fine ladies; not deficient in good humour 
when they were pleased, nor in the power of being agreeable when they chose it; but proud and conceited" (Austen 11). Elizabeth studies and judges the character of others; she makes assumptions about people based on her observations, like the one about Mr. Bingley's sisters, and later about Mr. Darcy. Her first encounter with Darcy leads her to the conclusion that he is proud and arrogant. She forms this estimation of his character from overhearing Darcy and Bingley talking while at an assembly ball in town. Sitting close enough to hear their conversation, Elizabeth catches his first opinion of her: "She is tolerable; but not handsome enough to tempt $m e$; and I am in no humour at present to give consequence to young ladies who are slighted by other men" (Austen 8). Elizabeth pays no mind to the slight and laughs about it while retelling the experience to her friends: "She told the story however with great spirit among her friends; for she had a lively, playful disposition, which delighted in anything ridiculous" (Austen 9). From the perspective of the traditional marriage plot, such a playful disposition is what she would need to grow out of for society to accept her as mature and eligible for marriage.

For the lover-mentor convention to be successful, the woman must learn from the man. Austen breaks this convention by having both the young lady and the lover-mentor character learn from each other. After Elizabeth overhears what Mr. Darcy thinks about her, she ignores him and feels he is only a nuisance. He tries his hardest to ignore her but fails when he realizes he is falling in love with her. For Austen to show Elizabeth's growth, as well as Darcy's, they must first make some bad decisions. Elizabeth must learn that she is not as good a judge of character as she thinks. Her evaluation of Mr. Wickham is very much off the mark and leads her sister into a potentially damaging situation. Being in the army, Wickham seems like an acceptable man, "His appearance was greatly in his favour; he had all the best part of his beauty, a fine countenance, a good figure, and very pleasing address" (Austen 62). Elizabeth and her 
younger sisters are infatuated with Wickham even before they are introduced. While the ladies and Wickham are talking, Bingley and Darcy stop and speak with the gathered group. Elizabeth, due to her prejudice against Darcy, misinterprets an exchange between Darcy and Wickham. There were no words exchanged between Darcy and Wickham, but the narrator notes:

Bingley was the principal spokesman, and Miss Bennet the principal object. He was then, he said, on his way to Longbourn on purpose to inquire after her [Jane]. Mr. Darcy corroborated it with a bow, and was beginning to determine not to fix his eyes on Elizabeth, when they were suddenly arrested by the sight of the stranger, and Elizabeth happening to see the countenance of both as they looked at each other, was all astonishment at the effect of the meeting. Both changed colour, one looked white, the other red. (Austen 62)

Although Elizabeth could not explain the men's exchange, she assumed Darcy had done something wrong to Wickham. The more acquainted she becomes with Mr. Wickham, the more she despises Mr. Darcy. After Wickham explains how Darcy mistreated him after Darcy senior died, Elizabeth wrongly judges Wickham as a decent man and Darcy to be even more despicable. When it is discovered that Wickham and Lydia have run off to Scotland, her opinion of him is no longer favorable. But this misunderstanding is later straightened out by Darcy. Mr. Darcy also takes the blame for breaking up Mr. Bingley and Jane. Elizabeth assumes Darcy separates them because Jane is not rich enough for Bingley, and she is partly correct.

After trying her hardest to ignore Mr. Darcy, Elizabeth is confronted with a proposal from him. Darcy's proposal is worse than Mr. Collins's because he insults her as well. Darcy's proposal shows that there are still aspects of his character that need reforming before he can marry Elizabeth. His proposal is centered on his feelings only; he does not once think about 
Elizabeth or her feelings. He enters the room and is visibly agitated, finally he says, "“In vain have I struggled. It will not do. My feelings will not be repressed. You must allow me to tell you how ardently I admire and love you.' Elizabeth's astonishment was beyond expression. She stared, coloured, doubted, and was silent. This he considered sufficient encouragement, and the avowal of all that he felt and had long felt for her immediately followed" (Austen 162). As Elizabeth sits stunned, Darcy continues to pour his heart out while laying bare her faults but none of his own. Austen does not have Darcy speak his proposal; we are given an account through the narrator:

He spoke well, but there were feelings beside those of the heart to be detailed, and he was not more eloquent on the subject of tenderness than of pride. His sense of her inferiority—of its being a degradation—of the family obstacles which judgment had always opposed to inclination were dwelt on with a warmth which seemed due to the consequence he was wounding, but was unlikely to recommend his suit. (162-163)

Darcy is convinced that his financial stability and profusions of love will sway Elizabeth to accept his hand in marriage. What he does not expect is her refusal because he has not yet learned to respect Elizabeth. She asks him why he is surprised by her rejection when "with so evident a design of offending and insulting me you choose to tell me that you liked me against your will, against your reason, and even against your character?" (164). In this scene, both characters show their need for improvement, and if they ever want to marry, they need to learn from what each other has said. Hazel Jones states, "Her refusal has powerful consequences for both of them: Darcy is stung into a mortifying review of his ungentlemanly conduct and Elizabeth is forced to re-evaluate her unfound prejudices. This is the beginning of a better knowledge of themselves and each other and from this point on they draw closer together" (29). 
It is interesting to think that a refused proposal would draw the two closer together, but after this, and his subsequent letter, Elizabeth starts to rethink her feelings about Darcy.

Elizabeth receives an apology/ explanation letter from Darcy the day after her refusal. This letter explains the situation with Wickham and how he is not what he seems. Darcy also explains his reasoning for breaking up Jane and Bingley, as he did not think she was genuinely in love with Bingley. Knowing his friend and how smitten he was with Jane, Darcy then watched Jane to see if she felt the same. He says, "Her look and manners were open, cheerful and engaging as ever, but without any symptom of peculiar regard, and I remained convinced from the evening's scrutiny that though she received his attentions with pleasure, she did not invite them by any participation of sentiment" (169). He admits he had judged her too quickly and did not understand her character; he was looking out for his friend. Wickham turns out to be a loathsome character who tried to marry Mr. Darcy's younger sister when she was only 15 years old. Wickham thought he could get more money out of Darcy by doing so. Luckily, Darcy intervened and saved his sister from a terrible marriage. Later in the novel, he intervenes again when Wickham seduces Lydia and then tries to leave her. After reading this letter and painstakingly recalling every interaction with Wickham, Elizabeth "grew absolutely ashamed of herself. Of neither Darcy nor Wickham could she think without feeling that she had been blind, partial, prejudiced, absurd. 'How despicably have I acted!' she cried. 'I who have prided myself on my discernments!... But vanity, not love, has been my folly"' (Austen 178-179). From this moment on, Elizabeth looks at Mr. Darcy in a different light. She has realized how childish her actions were and is determined to change and maybe win back his affections. Eventually, with encouragement from Elizabeth, Darcy makes a second proposal. As Laura Dabundo states in "The Feminist Critique and Five Styles of Women's Roles in Pride and Prejudice, "He reviews 
for her how he has changed, from having been an indulged only son who was, in his words 'selfish' and supercilious, especially toward those whom a class-based society considers his social inferiors" (47). Her first refusal teaches him not to look down on a person because of social standing and to recognize his own arrogance. Elizabeth has also changed; she has recognized her own limitations and feelings. This newly gained self-knowledge of both characters makes their marriage possible.

Darcy and Elizabeth's marriage is different from others in the novel in that it represents a new chapter in married life. Their marriage has the potential to teach the younger generation a different basis for marriage, one that includes a woman's desire and choice. Austen has created a loving, stable relationship for Elizabeth and Darcy, one that is based on trust and understanding rather than simply financial concerns. By completely discarding the convention of the perfect heroine and transforming the lover-mentor convention into a theme of mutual mentoring of both the man and the woman, Austen alters the marriage plot. In so doing, she paves the way for future novels to focus on women's desire and choice outside of marriage. 


\section{Persuasion: Choosing Spinsterhood}

Persuasion continues to alter the marriage plot by making the heroine a spinster. Anne Elliot had a chance to marry at a young age. Being unsure of herself, she listened to the prejudices of her friends and family, letting the love of her life slip away. Her refusal of Captain Fredrick Wentworth launches Anne into a self-appointed spinsterhood. While Elizabeth Bennet did not wait long for a second proposal, Anne waits eight long years. Within those years, Anne longs for the man she loves and regrets refusing him every day. In typical marriage plot fashion, the young woman has much to learn before she may marry, but her lover-mentor is not around to teach her. At the young age of nineteen, Anne receives a proposal from Wentworth. She accepts at first, but after Lady Russell, a woman she looks upon as a mother, and her family tell her the match would not be a good one as he is poor, she breaks the engagement. Their reaction to Anne's news is an example of the traditional mindset about marriage, from which Austen is moving away. Anne's father “on being applied to, without actually withholding his consent, or saying it should never be, gave it all the negative of great astonishment, great coldness, great silence, and a professed resolution of doing nothing for his daughter. He thought it a very degrading alliance; and Lady Russell, though with more tempered and pardonable pride, received it as a most unfortunate one" (26). Trusting Lady Russell's judgment, Anne "was persuaded to believe the engagement a wrong thing - indiscreet, improper, hardly capable of success, and not deserving it" (27). Even though she loves Wentworth, she lets him go. Being a member of the navy, Wentworth leaves shortly thereafter. Anne, having realized that she made a terrible decision, places herself in the role of a spinster. She must come to a conclusion on her own that marriage should be about love, not about money. As Sandra Gilbert and Susan Gubar point out in 
The Madwoman in the Attic, "Austen explores in Persuasion the effects on women of submission to authority and the renunciation of one's life story" (175). By rejecting the man she loves, Anne submits to the authority of her father and Lady Russell. In the years that follow, Anne pushes against the social norms and removes herself from the marriage market, holding on to hope that the man she loves returns to her.

Unlike Charlotte Lucas, Anne has had other opportunities to marry but chooses to remain single. This choice to be a spinster shows a woman having control over her life in the nineteenth century. Granted, Anne comes from a wealthy family and thus has the means to remain single for now. Remaining single, though, means she must cater to her family's every whim. Her father and sisters are not as mature as Anne. Her father is extremely vain and self-centered, much like her eldest sister, Elizabeth. Mary, the youngest, is continuously in need of Anne's help with her two young children. Neubauer states, "Anne Elliot in Persuasion is, like Charlotte Lucas, twentyseven years old and clearly the intellectually superior person in her otherwise vain and rather silly family" (130). Being a baronet, Sir Walter is one of the elites of the world and therefore objects to his daughter marrying someone of a lower status. His vanity is seen in two of his daughters. Elizabeth is the most like her father; she is self-centered and degrades the lower class. Elizabeth's social position is not as stable as her father's, and when he passes, she and Anne will find themselves without a home.

Mary, too, considers herself better than others because of her father's baronetage. Anne is the black sheep of the Elliot family, more like her mother, "sensible and amiable" (Austen 6). Her family thought of her as nobody: Anne, "with an elegance of mind and sweetness of character, which must have placed her high with any people of real understanding, was nobody with either father or sister: her word had no weight; her convenience was always to give way;- 
she was only Anne" (Austen 7). By treating Anne as a nobody, her family solidifies her stance as a spinster. Jean B. Kern observes how "Anne has both been neglected and ignored by both her father and her older sister who never take her to London for the season. Her younger married sister has exploited her to act as a nurse during Mary's hypochondriacal illnesses or as a 'sitter' and disciplinarian of her two unruly little sons" (211). Being taken advantage of and so drastically different from her family makes it easier for Anne to leave the landed gentry behind when the time comes.

Although Charlotte in Pride and Prejudice and Anne are both twenty-seven, their roles as spinsters are different. Charlotte is actively looking for a way out, while Anne accepts her singleness. Austen makes a statement about spinsterhood with Anne Elliot. By having a female character actively remove herself from the marriage market for seven years and then decide to marry, she shows that spinsterhood is not a life sentence. Austen is altering the idea of marriage and singleness by giving an older female character a choice in her life. In "Choosing Spinsterhood: Enacting Singleness in Persuasion," Dashielle Horn states, "Persuasion shows spinsterhood to be a construct imposed on unmarried women and, more radically, that spinsterhood can be a position adopted by choice" (236-237). Elizabeth is also unmarried but treated entirely different than Anne. Because Anne chooses to remain single and be pushed around, she is in the background of their lives, there to haunt her family. Within the first volume of the novel, Anne is shown to be a background figure. She speaks, but no one listens to what she has to say. When there are parties where young people dance and interact, Anne plays music for them. By doing so, she creates a barrier between herself and the marriage market. The piano ensures that no one will ask her to dance, giving no opportunity for another proposal. She also takes care of her family, accepting the role of spinster aunt. Horn observes that Anne "preforms 
spinsterhood herself in two ways: she refuses to participate in the marriage market, and she opts instead for a devotion to helping others, enacting behavior typical of the spinster aunt" (329). Her role as spinster aunt has given her motherly qualities without having children. Even though Anne is unappreciated by her family, she still helps even when she is not wanted.

Anne's role as spinster, and her decision to be persuaded, has given her a maturity that she would not have had if she married Wentworth at a young age. Gillian Beer, in the introduction to the Penguin edition of Persuasion, comments on Anne's decision to be persuaded, as well as Anne's own ability to persuade later in life: “Anne, so adept at persuading others in order to smooth daily living, is constantly in two minds about whether she had been right to be persuaded by Lady Russell long ago to give up Wentworth" (xvii). Having time to reflect on her decision to be persuaded by Lady Russell, Anne learns to think for herself and wants to lead a life of her own, something she did not do when Wentworth first proposed. Anne's ability to act in stressful situations where others would hesitate gives her an advantage in the world. Her reaction when her nephew dislocates his collarbone shows her levelheadedness: "Anne had everything to do at once — the apothecary to send for- - the father to have pursued and informed - the mother to support and keep from hysterics — the servants to control — the youngest child to banish, and the poor suffering one to attend and soothe" (Austen 50). Austen gives Anne the decision-making skills often portrayed in male characters. Anne's ability to think clearly when there is a crisis is not a common trait among women of her time. With her characters, Austen refuses the notion that women are weak, passive, and deficient. This calm capability would serve her well in life if she were to remain single.

Elizabeth, on the other hand, will be in a different situation if she never marries. Elizabeth's spinsterhood is different from Anne's in that she has taken over for their mother. At 
sixteen years old, Elizabeth takes over the duties as mistress of Kellynch Hall. Thirteen years later, Elizabeth is still unmarried and has been perfectly content with her situation. Her position as mistress gives her the power of a married woman: "For thirteen years had she been doing the honours, and laying down the domestic law at home, and leading the way to the chaise and four, and walking immediately after Lady Russell out of all the drawing-rooms and dining-rooms in the country" (Austen 8). Anne and Elizabeth, having only two years age difference, have aged differently: "[Anne] had been a very pretty girl, but her bloom had vanished early" (7). At the same time, Elizabeth "was fully satisfied of being still quite as handsome as ever" (8). Elizabeth is now twenty-nine and hoping someday soon a man of baronet-blood will solicit her. She has had her eye on the heir presumptive, Mr. William Elliot, for quite some time until they discover that he is married. Now Elizabeth must wait for another of equal birth. The fact that Elizabeth, at twenty-nine, is still in her bloom and eligible for marriage, helps support the idea that "spinsterhood is less about age and more about the failure to attract a husband-a failure that one is not expected to rebound" (Horn 238). Elizabeth may still have her bloom, but Anne has more of a chance in acquiring a husband. Anne's standards are not as high as Elizabeth's. In her portrayal of the sisters, Austen is proving that spinsterhood is a position that can be changed if the woman chooses.

Elizabeth has not effectively managed Kellynch Hall. She and her father's extravagant lifestyle has created a financial problem for the family. Lady Elliot had kept Sir Walter's spending under control while she was alive, but now there is no one to tell him no. Sir Walter seeks help from Lady Russell, who turns to Anne for help in making a budget for her family. Anne's retrenching is too much for her father. She creates a plan that would cut back on their extra, unnecessary expenses. Their foolish spending and refusal to live less lavishly leads Sir 
Walter to the decision to rent out their home. While they have someone living in their home, Sir Walter and Elizabeth decide to stay in Bath instead of a less expensive country home. Anne is not a fan of Bath but luckily is needed at her younger sister's house for a while. The family to let Kellynch-hall are Admiral Croft and his wife. To Anne's dismay, Mrs. Croft is Wentworth's sister, and she finds out that he will be visiting during their stay. Anne's family's spending habits have lead Wentworth back into her life.

While the Crofts are staying in Kellynch, and her father and Elizabeth in Bath, Anne is with her sister Mary in the Cottage at Uppercross, the Musgrove's home. Married to Charles Musgrove, Mary portrays the life Anne could have had. Charles had initially asked Anne to marry him: "she had been solicited, when about two-and-twenty, to change her name, by the young man, who not long afterwards found a more willing mind in her young sister" (Austen 28). Anne married to Charles would not be what Mary married to Charles has become. Anne is of a completely different mindset than her sister and would probably have made Charles into a better, more focused man. Charles is not a bad match for Anne, but she refuses him because she wants a marriage based on love, like Elizabeth Bennet. She would have had that with Wentworth, but at the time he proposed, they both were not ready for marriage. Charles is not like other rejected suitors in Austen novels. As Horn states, "Charles has none of the repugnant qualities of Austen's other rejected suitors. He is neither a pompous buffoon like Mr. Collins nor a sly, social-climbing Mr. Elliot. Musgrove shows none of the moral failings of Henry Crawford, and he has suitable wealth and social status to solicit a gentlewoman's hand. In Austenian logic, there is no discernible reason not to marry him" (240). Anne is actively keeping herself out of the marriage market by refusing Musgrove's proposal, knowing that her family will continue to treat 
her poorly, and holding on to hope that her true love will return. Being in the Musgrove household again shows Anne in the spinster aunt role.

Being so close to Wentworth creates anxiety for Anne. While she stays at the Cottage with the children, her sister and Charles are at Uppercross having dinner with the Musgroves, Crofts, and Wentworth. She would like to see him again but is unsure if he feels the same. She believes that if he had wanted to see her before now, he had the ability to do so, while she did not. The next morning Wentworth visits the Cottage to go shooting with Charles. She finally sees him after eight years, and their interaction would never lead the reader to guess that the two were once engaged: "Her eyes half met Captain Wentworth's; a bow, a curtsey passed" (Austen 56). Anne thought her feelings for Wentworth had disappeared over the eight years they have been separated, but upon seeing him again, her feelings rise to the surface. She soon believes that Wentworth's feelings for her no longer exist when Mary says, "Henrietta asked him what he thought of you, when they went away; and he said, 'You were so altered he should not have known you again"” (Austen 57). Hearing this, Anne cannot help but feel wounded. She then reflects on Wentworth and his appearance: "she could not take revenge, for he was not altered, or not for the worse... the years which had destroyed her youth and bloom had only given him a more glowing, manly, open look, in no respect lessening his personal advantages. She had seen the same Frederick Wentworth" (Austen 57). With the knowledge that he no longer cares for her and finds her changed, Anne tries to move on from Wentworth.

In line with the marriage-plot novel, Austen makes the characters work for their happily ever after. After their ungenial reunion, Anne and Wentworth find themselves repeatedly in each other's company. Anne has indeed changed since Wentworth last saw her, and she must show him that if she is to win his affection once again. At this point, Austen reverses the marriage plot 
by having Wentworth as the student and Anne, the teacher. Wentworth needs to see that Anne is no longer the young girl who was easily persuaded by others. She has become a strong, independent woman capable of thinking for herself. Anne must show him how much she has changed, and in turn teach him a lesson on not judging a person by their past mistakes. Anne has already learned on her own that she was wrong to listen to Lady Russell; now she must show Wentworth that he is wrong to view her as weak, and that she should be treated as his equal. Wentworth's view of women needs to change for him to marry. Elvira Casal, in "More Distinguished in His Domestic Virtues: Capitan Wentworth Comes Home," explains:

Because Wentworth usually appears to the reader through Anne's eyes, and because so much of the novel is dominated by Anne's regret for the decision that separated her from Wentworth, it is easy to overlook the ways in which Wentworth's limited understanding of women, caused in part by lack of domestic experience, is responsible for much of the separation. Yet a central strand in the novel is the account of Wentworth's growth as a person, as he comes not only to recognize Anne's real value, but, by extension, to revise his views about women in general (147).

Wentworth must stop patronizing women for not being as strong-willed as men and instead view them as equals. He judges Anne for being so easily persuaded by other years ago and complements Louisa for what he sees as "decision and firmness" of character (Austen 81). Being in the navy from a young age, Wentworth has little experience in the domestic arena; once Anne realizes he still has feelings for her, she can help him change.

Wentworth expresses to his sister that he is actively looking for a wife, one with “" $\mathrm{A}$ strong mind, with sweetness of manner,' made the first and the last of the description" (Austen 58). Anne is not wholly out of consideration in his search for a wife, but he still holds in his mind 
the old version of Anne and how she broke his heart. Anne has a difficult task in getting Wentworth to realize that she still loves him. While he is visiting, Wentworth is also in the company of the Miss Musgroves. A small town offers a limited number of people with whom to interact. Wentworth, as a new, handsome, marriageable man, is someone with whom girls were eager to win favor. While in the countryside, Anne must watch as Wentworth flirts with other women. She must watch as Henrietta and Louisa dance with him while she, as usual, plays the music. She watches while the man she loves disregards her for someone else. Anne must listen to Mary and the Miss Musgroves contemplate who Wentworth will ask to marry.

Henrietta had shown interest in another man, her cousin, Charles Hayter, before Wentworth arrived, and now he has returned for her hand. Anne, being ever so reliable, must listen to her sister and brother-in-law argue about to whom they thought Wentworth was going to propose. Being in the background has helped Anne develop her ability to read people, a skill Elizabeth Bennet would envy. Anne observes the Miss Musgroves, Wentworth, and Charles Hayter to see if she can discern Wentworth's true feelings. She can sense that Wentworth still has feelings for her, but she needs to know for certain before she attempts to win him back. Anne knew, "as far as she might dare to judge from memory and experience, that Captain Wentworth was not in love with either. They were more in love with him; yet there it was not love. It was a little fever of admiration; but it might, probably must, end in love with some" (Austen 76). She goes on to say how she would like to tell them all how foolish they were acting. Wentworth finally sees how much Anne has changed when Louisa jumps from a wall and knocks herself unconscious. From this point on, Wentworth sees Anne in a new light.

An example of Wentworth still judging Anne for her treatment of him in the past is the speech he makes to Louisa while out for a walk. Anne is resting behind the hedge-row, covered 
by a low bush, when she overhears their conversation. Louisa is telling Wentworth how she insisted Henrietta make up her mind and either let Hayter know she no longer wants an attachment or break it off. Wentworth praises Louisa for her firmness of character and states, "It is the worst evil of too yielding and indecisive a character, that no influence over it can be depended on...My first wish for all, whom I am interested in, is that they should be firm" (Austen 81). Wentworth shows just how little he understands the sacrifice Anne made by canceling their engagement. He still has a lot to learn about women, and Anne's quick thinking when Louisa is injured begins to change his mind. Anne keeps a level head while instructing the others and supporting Louisa's weakened sister. Anne cannot go to the girl but instructs them to “'Rub her hands, rub her temples; here are salts'... everything was done that Anne had prompted, but in vain; Captain Wentworth, staggering against the wall for support, exclaimed in the bitterest agony, 'Oh God! Her father and mother!' 'A surgeon!'” (101). While the group panics, Anne remains calm, directing the others when they cannot think of what to do for the unconscious girl. Louisa remains in bed to recover, with the company of Captain Benwick, a sensitive man once engaged to Captain Harville's sister. Both are friends of Captain Wentworth. After Louisa's fall, Anne leaves for Bath.

While in Bath, Wentworth must now watch as Anne flirts with someone else. Her cousin Mr. Elliot has returned, and he is personable and giving Anne attention she has not had in a while. But when she is reunited with an old friend, Mrs. Smith, she discovers Mr. Elliot's real character. Wentworth sees them together and thinks it is over for him until Anne makes a speech that changes his mind. Captain Harville and Anne are talking, while Wentworth listens, about women's constancy. Anne argues, 
[Women] certainly do not forget you, so soon as you forget us. It is, perhaps, our fate rather than our merit. We cannot help ourselves. We live at home, quite, confined, and our feeling prey upon us. You are forced on exertion. You have always a profession, pursuits, business of some sort or other, to take you back into the world immediately, and continual occupation and change soon weaken impressions. (218)

Anne is trying to articulate that women have such sheltered lives that they have no distractions to keep them from dwelling on the men they love. Men have more outside interests, giving them the ability to recover from a loss sooner than women. It is in this moment that Wentworth finally understands Anne; her talk with Captain Harville was implicitly directed to Wentworth as an explanation of her prior actions and present feelings. Wentworth leaves her a letter, in true Austenian fashion, confessing his feelings and asking again for her hand in marriage. In his letter, he states, "Unjust I may have been, weak and resentful I may have been, but never inconstant" (222). He confesses that he held a grudge for eight years, but now that he knows that she broke the engagement for good reason, he can accept her decision and move forward. Their marriage removes Anne from the landed gentry and places her in a newly mobile society. Leaving behind her father's baronetage, Anne and Wentworth create a new family within the navy. Like Elizabeth and Darcy, Anne and Wentworth represent the future of marriage.

At the start of the novel, Anne has been a spinster for eight years. In the end, she has the man she loves. Even though she could have married Charles Musgrove, Austen insists that her heroines create a marriage that is based on love, not convenience. Charles is not a repulsive man like Mr. Collins, and they could have had a comfortable life, but Austen does not want her heroines to settle for comfortable. In altering the marriage plot, Austen creates relationships, not just marriage contracts. Austen's work paves the way for future women writers to explore new 
paths for single women in a male-dominated world. Her novels show that spinsters do not need to be viewed as objects of ridicule or pity. Before she marries Wentworth, Anne is a spinster who proves herself to be a highly competent, decisive woman on whom others depend. While following the basic marriage plot, Persuasion nevertheless again alters it by forcing the man, not just the young woman, to learn and grow, and by presenting a character in the spinster position as strong and capable. 


\section{Mrs. Dalloway: Spinsterhood and Sexuality}

Virginia Woolf followed in Jane Austen's footsteps by giving women a choice in her novels. Her work, A Room of One's Own, argues that women need a space, away from everyone else, where they can retreat and create. Women need the same opportunities as men if they are ever to make it in the male-dominated society. Mrs. Dalloway shows women from all walks of life dealing with their constrained circumstances. The female characters are often shown practicing an art or craft as a creative outlet. Most upper-class women followed their Victorian predecessors by staying home while their husbands worked, giving them a need for entertainment. In Mrs. Dalloway, as Ann Ronchetti observes, Miss Kilman leads a marginal existence tutoring Elizabeth Dalloway in history, attending religious services and lectures, and, despite her tin ear, attempting to play the violin as a source of consolation... Sally demonstrates pride in her five sons and her extensive beds of rare hibiscus... Lady Bradshaw accompanies her physician husband on his rounds, patiently waiting in his elegant gray car, or taking professional-grade photographs of old churches nearby. Among the remaining female characters, two of an even older generation have been more successful in channeling their creative energy into unusually productive activities. $(50-51)$

While Miss Kilman is not from the upper-class or married, she still finds a way to be productive. The other women find something to ease the boredom of daily life for a wealthy, married woman. Being from a world of privilege and having husbands who have high social positions, some of the women find life restricting. Clarissa finds the role of wife to a Member of Parliament fitting. She has always been partial to the role of hostess, a primary reason for marrying Richard. Her parties are known for their excellence and are an example of Clarissa's social artistry. 
Clarissa's flashbacks show the choice she made to marry a man and appease social expectations. Like Anne in Persuasion, Clarissa in Mrs. Dalloway reminisces about her youth and her missed opportunities at love. Comparable to Charlotte Lucas in Pride and Prejudice, Clarissa chooses a life that she knows will give her the most security and comfort. Like Anne, she had a chance at love with a man who was considered below her, but she saw that he wouldn't give her the freedom she wanted: "with Peter everything had to be shared; everything gone into" (Woolf 8). At the same time, she realized she was attracted to her best friend, Sally Seton. Instead of remaining single and exploring her sexuality, which is socially unacceptable, she chooses to marry Richard Dalloway. With Richard, Clarissa has a freedom that a life with Peter or becoming a spinster would not. Richard does not demand that she share her feelings and thoughts with him as Peter would. As Jesse Wolfe states in "The Sane Woman in the Attic: Sexuality and Self-Authorship in Mrs. Dalloway," "Unlike Peter's love, Richard's is not oppressive. It provides Clarissa with space, both physically (a room and ominously narrow bed of her own) and psychically (in which to work through her problems, to live a private life)" (36). By marrying Richard, Clarissa conforms to societal norms and becomes a wife and mother while also allowing her to fulfill her role as hostess. Being the wife of an MP, Clarissa can put together parties for dignitaries, while also bringing people together as a way of combatting isolation and loneliness.

In her youth, Clarissa showed interest in literature while also being fond of social life. It seemed that she was destined to marry a well-to-do man even if she had feelings for a woman. In one of her flashbacks, the reader is made aware of her experience with Sally. Sally was everything Clarissa was not: free-spirited, open-minded, rebellious, and poor. One summer at her parent's country home, Bourton, the two made plans to change the world. Clarissa became 
enthralled with Sally: she "read Plato in bed before breakfast; read Morris; read Shelley by the hour" (Woolf 33). Sally taught Clarissa about life and love: "The strange thing, on looking back, was the purity, the integrity, of her feelings for Sally... Then came the most exquisite moment of her whole life passing a stone urn with flowers in it. Sally stopped; picked a flower; kissed her on the lips. The whole world might have turned upside down!" (34-35). Clarissa's life is changed after this kiss; nothing can compete with this experience. In the article, "Clarissa's Attic: Virginia Woolf's Mrs. Dalloway Reconsidered," Shalom Rachman explains, "It was an experience of love of her friend, Sally, and the only time Clarissa felt the passion of love. At the time it seemed to her to be 'protective' love on her part, yet the strength of her passion was overpowering... And 'the most exquisite moment of her whole life' - the 'religious feeling' she experienced- was when Sally kissed her on the lips" (10). Clarissa hasn't experienced anything else in her life to equal this moment—not her marriage to Richard or even the birth of her only child. Sally, in her younger years, is everything Clarissa wants to be. She knows, however, that she must continue performing the role that society, and her social standing, have marked out for her. Due to her lingering feelings for a woman, Clarissa feels she has failed Richard sexually. She recalls, suddenly there came a moment — for example on the river beneath the woods at Clieveden — when, through some contraction of this cold spirit, she had failed him. And then at Constantinople, and again and again. She could see what she lacked. It was not beauty; it was not it was not mind. It was something central which permeated; something warm which broke up surfaces and rippled the cold contact of man and woman, or of women together. (31) 
Even though Clarissa loves Richard, she does not think of him sexually as she does Sally. By marrying Richard, however, Clarissa avoids becoming a spinster and leaves her true sexuality in the past. If Clarissa had chosen a different path or followed her heart, her life would be completely different. Clarissa believes that she would have ended up like Miss Kilman, her daughter's spinster governess.

At the time Mrs. Dalloway was written, the term "spinster" was starting to shift. The twentieth-century spinster must now combat attacks on her sexuality, an attack not known to nineteenth-century spinsters. Nineteenth-century spinsters were thought to have failed to attain a husband; the idea that perhaps the single woman was not attracted to men would not have crossed anyone's mind. Mrs. Dalloway's most notable spinster is Doris Kilman; many critics in fact see her as Clarissa's alter ego. If Clarissa had acted upon her genuine desires and had not married, her life could have been like Miss Kilman's, a governess who teaches history to wealthy men's children (after being removed from a teaching position due to the war). Doris and Clarissa's similarities are explored in Kenneth Moon's article, "Where is Clarissa? Doris Kilman and Recoil from the Flesh in Virginia Woolf's Mrs. Dalloway." He states, "Kilman is a historian, specializing in Russia. Clarissa, somewhat similarly, reads memoirs; and Barron Marbot's, her current reading, deals with the retreat from Moscow. Also, each has a sibling destroyed young: Clarissa's Sylvia by a falling tree, Kilman's brother in the War" (276). Clarissa's life would not mirror Doris's, but becoming a teacher would have been a possibility. The two women are not fond of each other in the least. When Clarissa thinks of Kilman, she likens her hatred of her to a "brutal monster." This hatred, rasped her, though, to have stirring about in her this brutal monster! to hear twigs cracking and feel hooves planted down in the depths of that leaf-encumbered forest, the 
soul; never to be content quite, or quite secure, for at any moment the brute would be stirring, this hatred, which especially since her illness, had power to make her feel scraped, hurt in her spine; gave her physical pain, and made all pleasure in beauty, in friendship, in being well, in being loved and making her home delightful, rock, quiver, and bend as if indeed there were a monster grubbing at the roots, as if the whole panoply of content were nothing but self-love! this hatred! (12)

Clarissa admits that it is not the woman she "hated but the idea of her, which undoubtedly had gathered into itself a great deal that was not Miss Kilman; had become one of those spectres with which one battles in the night; one of those spectres who stand astride us and suck up half our life-blood, dominators and tyrants" (Woolf 12). That "spectre" here is spinsterhood, being alone and unloved, and what Clarissa could have become if she had not married Richard. Clarissa works tirelessly to drown her sexual frustration created by the feeling that she has failed her husband.

Miss Kilman represents what Clarissa detests and fears about herself and her unacknowledged sexuality. Doris has a similar reaction to Clarissa; while waiting for Elizabeth, Doris has an overpowering desire to dominate Clarissa. Doris reflects on her past and states:

She [Clarissa] came from the most worthless of all classes - the rich, with a smattering of culture... She pitied and despised them from the bottom of her heart...Bitter and burning, Miss Kilman had turned in to a church two years three months ago...The Lord had shown her the way. So now, whenever the hot and painful feeling boiled within her, this hatred of Mrs. Dalloway, this grudge against the world, she thought of God. (123-124) While Clarissa's "spectre" is spinsterhood, Miss Kilman's is the rich and her own envy and resentment of them. Another comparison of the two women occurs when Woolf places each on 
the same street and recounts their observations. While Clarissa takes in the hustle and bustle of Victoria Street and embraces it, Doris's reaction can be read as sexually charged and threatening. Moon summarizes their reactions: "Clarissa sums up her response to Victoria Street as 'life, London, this moment of June,' and this is the Clarissa initially presented to us - the evidently eager, live-embracing Clarissa. But Kilman's response is of disgust, rejection: 'It is the flesh!'” (277). Doris's reaction to Victoria Street is a reaction to masculinity. The way she describes "the assault of carriages, the brutality of vans, the eager advance of myriads of angular men, of flaunting women" (Woolf 128) is combative and a reflection of how society has treated her. Clarissa, on the same street, sees it differently because she has conformed to society and is accepted by it. Doris, being a spinster and having masculine qualities herself, finds society threatening. Elizabeth also forms a connection between the two women. Each woman is trying to impart their worldviews on the young girl while she decides what to make of her life. While women are becoming more involved in society in Woolf's time, spinsters are still considered an oddity and are treated especially poorly when they are from the lower-class.

One would think that the condition of spinsters should have improved over time, but as Laura L. Doan observes, that is not the case. In Old Maids to Radical Spinsters: Unmarried Women in the Twentieth-Century Novel, Doan notes, Inasmuch as the modern novel coincides with the historical moment when the spinster herself is disappearing and the spinster as a significant concept is challenged as problematic, it seems all the more imperative that we extend our attention to the twentieth century. The only book-length study of the spinster in the twentieth-century literature remains Dorothy Yost Deegan's The Stereotype of the Single Woman in American Novels, published in 1951. (7) 
Doan, as well as Deegan, claim that there is not much criticism on the representation of the spinster in literature. Deegan combs through novels published from 1800 to 1945, finding that "single women were usually objects of pity or ridicule. Deegan writes that 'almost without exception [spinsters] are old and drab and unattractive... For Deegan, the improved social position of women in the twentieth century should have culminated in a more positive image of the single woman, but, paradoxically, the old stereotype persists" (Doan 8). Spinsters still occupy jobs such as teacher, governess, and dressmaker because those positions are all that is available to them. Miss Kilman fits this stereotype, but another spinster in Mrs. Dalloway fairs better. Clarissa's maiden aunt, Miss Parry, had adventures in her youth; "old Miss Parry, was in her younger years the picture of energetic Victorian spinsterhood, having traveled widely (and dangerously) in Burma, collecting orchid specimens and documenting them in her watercolors" (Ronchetti 51). Miss Parry had the means to travel, whereas spinsters from the lower classes did not have that luxury. Woolf's older spinster characters are reflective of the past, while her up and coming young women show a possible change for single women.

Elizabeth Dalloway, at seventeen, is just entering the world. Audra Dibert-Himes points out in "Elizabeth Dalloway: Virginia Woolf's Forward Look at Feminism," that Elizabeth is most often "described in contrast to Clarissa, with no mention of her family, but in comparison to Richard and the Dalloways" (225). Throughout the novel, Woolf draws comparisons between Elizabeth and her father. Clarissa comments on her daughter's looks by saying, "Was it that some Mongol had been wrecked on the coast of Norfolk... For the Dalloways [women], in general, were fair-haired; blue-eyed; Elizabeth on the contrary, was dark; had Chinese eyes in a pale face; an Oriental mystery; was gentle, considerate, still" (Woolf 123). Elizabeth does not share any features with her mother; she takes after her father. It is even commented that she has 
the same disposition as her father, always caring about animals. Woolf is moving away from the "Angel in the House" figure and more towards what she believes women of the future will become. This "angel" is the idealized characterization of the domestic woman that nineteenthcentury male writers established. The woman is the perfect example of what a wife should do for her husband and family. Woolf wants to "kill" this angel and create female characters who are more realistic and think for themselves. Gilbert and Gubar state, "a woman writer must examine, assimilate, and transcend the extreme images of 'angel' and 'monster' which male authors have generated for her...women must 'kill' the aesthetic ideal through which they themselves have been 'killed' into art" (17). Women are more than just wives and mothers, and Woolf is demonstrating though her fiction that there needs to be more representation of real female characters, even though Miss Kilman represents an outdated view of spinsters. Elizabeth's character displays the future of womanhood.

Elizabeth's thoughts on her future are based on her response to the adults in her life: "Although Miss Kilman and Clarissa are at odds, one is trying to control and possess Elizabeth, and the other upset over how Kilman is going to destroy 'the privacy of the soul' through 'love and religion,' neither of them overwhelms Elizabeth" (Dibert-Himes 225). Elizabeth rejects both her mother's life as well as Miss Kilman's, opting instead to create her own future. Doris tells Elizabeth that she has more opportunities open to her than she herself did, but she still wants her to follow her lifestyle. Dibert-Himes points out that "Although Miss Kilman tells Elizabeth that young women can be anything they want to be, the older woman's lifestyle belies the fact that in her value and belief system, a woman must be within a hierarchy (the church), have male guidance (Mr. Whittaker, her spiritual adviser), and pursue a traditional female role (a teacher)” (226). To represent Elizabeth's refusal of this lifestyle, Woolf has her cross Victoria Street and 
travel to the Strand, a place neither Mrs. Dalloway nor Miss Kilman ever venture. As she waits for an omnibus, Elizabeth reflects on herself and how she does not want to be a part of the city: And already, even as she stood there, in her very well cut clothes, it was beginning... People were beginning to compare her to poplar trees, early dawn, hyacinths, fawns, running water, and garden lilies, and it made her life a burden to her, for she so much preferred being left alone to do what she liked in the country, but they would compare her to lilies, and she had to go to parties, and London was so dreary compared with being alone in the country with her father and the dogs. (Woolf 134-35)

In this passage, Woolf is trying to convey that Elizabeth has no desire to be in the world of her mother; she did not care about her looks or if people found her attractive. All she wants is to be left alone and not be compelled to entertain people, like her mother. By taking that omnibus ride, Elizabeth thinks herself a rebel. While on the bus, she thinks of all the job opportunities open to her now; these are more masculine roles that Victorian women never previously dreamed of holding.

By portraying Miss Kilman as the detestable spinster, Woolf shows that she is not quite ready to accept that spinsterhood can be a good position for a woman. Elizabeth starts to shift her thinking on spinsterhood, but Woolf still comments on the men that are beginning to notice Elizabeth, which suggests her inevitable march down the aisle. Emma Liggins, in Odd Women? Spinsters, Lesbians and Widows in British Women's Fiction, 1850-1930s, comments about new possibilities for women in the workplace in Woolf's Three Guineas, stating, "Virginia Woolf's polemic Three Guineas (1938) welcomed the Sex Disqualification (Removal) Act of 1919, which 'unbarred the professions' to women, as a moment of 'excitement' and 'pride', allowing the educated man's daughter to 'issue from the shadow of the private house' onto 'the bridge 
which lies between the old world and the new" (207). Elizabeth acts as the bridge between her mother and Miss Kilman, and she represents a bridge to greater opportunities for women, about which they can now at least dream. 
To the Lighthouse: The Evolution of the Spinster as Artist

Virginia Woolf continues to explore marriage and spinsterhood in To the Lighthouse. Within this novel, Woolf acknowledges the spinster and shows her character thriving by creating art. In order to do this, the spinster character, Lily Briscoe, must first cast aside her infatuation with Mrs. Ramsay and become an independent woman. While spending the summer at the Ramsay's island house, Lily attempts to paint Mrs. Ramsay and her youngest son while looking at them through the window. Lily cannot finish the picture before they must leave, and for years after, she still thinks about the image and how she should finish it. At thirty-three, Lily has no desire to marry, and from the example of the Ramsay's marriage, she does not mind remaining single. Before Lily can fully embrace her single, unmarried life, however, she will need to free herself from the power that Mrs. Ramsay, in her role as ideal wife and mother, exerts over her.

The Ramsay's marriage is reflective of the Victorian era, where the husband goes to work while the wife stays home and takes care of the house and children. In her article "Where the Spear Plants Grew: the Ramsays' Marriage in To the Lighthouse," Jane Lilienfeld points out that "Woolf's vision of the Ramsays' marriage is a mature, sharp critical examination not only of the relations between her own parents, but also of the destruction wreaked by the Victorian social arrangement on human capacities for freedom and growth" (149). It is often noted that To the Lighthouse is comparable to Woolf's childhood. Her father, Leslie Stephen, agreed with Victorian era ideas that "it was natural law that a wife should have no legal rights, no right to her own property or money, no training for any job, nor any hope to obtaining one" (Lilienfeld 151). This is an ideal to which Mr. Ramsay adheres as well. Despite progress in women's rights at this time, the mindset of the nineteenth century still lingers. 
The Ramsays play an important role in Lily's development as a single woman. Mrs. Ramsay is portrayed as the Angle in the House, the mother to eight children who is always caring for others. Woolf first spoke of the Angel in the House in a paper titled "Professions for Women" that was read to the Woman's Service league in 1931 (Showalter 339). Elaine Showalter, in her article "Killing the Angel in the House: The Autonomy of Women Writers," explains, "Woolf visualized the oppressive phantom as a graceful young woman, the spirit of Victorian womanhood, who hovered over her as she wrote, and whispered, 'Be sympathetic, be tenser; flatter; deceive... Never let anybody guess that you have a mind of your own... Yet this exemplary female had always been a male ideal rather than a living woman" (340). Mrs. Ramsay is the Victorian ideal of womanhood that Lily must overcome so that future women can thrive independently. Mrs. Ramsay plays the role of the Victorian wife for her husband, being dependent on him and having a limited education. But this does not stop her from helping others.

Like Mrs. Dalloway, Mrs. Ramsay is a social artist. Instead of planning elaborate parties, Mrs. Ramsay raises her children and cares for the lower-class in her community. She also plays matchmaker, and insists that women must marry. Ann Ronchetti states, "With Mrs. Ramsay, Woolf expands her portrait of the traditional wife and mother as social artist and engineer of relationships as well as creator of enduring moments of community and order in the face of life's arbitrariness and nature's indifference to humankind" (65). Woolf explores Mrs. Ramsay's role as mother and social artist in greater detail by setting her in an isolated summer home. Mrs. Ramsay is "never alone for several hours at a time, as is Clarissa, during the course of her day. Rather, one obtains both glimpses and in-depth views of the various forms Mrs. Ramsay's artistry takes hour by hour throughout the first part of the novel" (Ronchetti 66). Even when she has a chance to be alone while she walks into town to check on the poor families, she invites one 
of her guests to join her. That guest is Charles Tansley, a student of her husband, who is mocked by her children as the atheist. What the children do not like about him is his egoism; they say "when they talked about something interesting, people, music, history, anything, even said it was a fine evening so why not sit out of doors, then what they complained of about Charles Tansley was that until he had turned the whole thing round and made it somehow reflect himself and disparage them - he was not satisfied" (Woolf 8). Charles reveals on their walk that he has a difficult life, and Mrs. Ramsay pities him for not having a childhood. Mrs. Ramsay believed that men needed to be taken care of, coddled, and that women could fend for themselves. She feels "she had the whole of the other sex under her protection; for reasons she could not explain, for their chivalry and valor, for the fact that they negotiated treaties, ruled India, controlled finance" (Woolf 6). Lily cannot understand Mrs. Ramsay's feeding into these patriarchal ideas, and she needs to break away from them.

In having Mrs. Ramsay act as a nurse for the poor families in the neighborhood, Woolf follows the Victorian idea put forth by Sarah Stickeney Ellis. Lilienfeld explains that Ellis's conduct book told woman that they were inferior to men. She quotes Ellis as saying, "[remember] the superiority of your husband simply as a man. It is quite possible that you may have talent, with higher attainments, and you may also have been generally more admired, but this has nothing whatever to do with your position as a woman, which is, and must be, inferior to his as a man" (151). As a woman, Mrs. Ramsay might be inferior to her husband, but she has the ability to manipulate men and get her own way. At the beginning of the novel, her youngest son James wants to go to the lighthouse, and Mr. and Mrs. Ramsay ague about it. Mr. Ramsay says they cannot go because it will rain, while Mrs. Ramsay give the child hope that it will not. By not agreeing with her husband, Mrs. Ramsay fights against the idea that a woman must always 
submit to her husband and follow his rule. Lilienfeld explains more of Ellis's conduct book and how the wife should act:

'The great business of [a married woman's] life is to soothe and to cheer, not to depress, to weary, or to annoy.' According to Mrs Ellis, this angel did not require anything beyond the good done by her self-abnegation. For, 'if the wife can thus supply to the extent of [her husband's] utmost wishes, the sympathy, the advice, the confidence, and the repose, of which he is in need she will have little cause to think herself unfulfilled.' (154)

This idea that the wife should coddle her husband and be always sympathetic is something Mrs. Ramsay, to some extent, at times resists. The Ramsays' argument over going to lighthouse is an example of Mrs. Ramsay pushing back. While Mrs. Ramsay is comforting James, she disregards Mr. Ramsay and his authority, saying, "How did he know? she asked. The wind often changed" (Woolf 31). This remark leads Mr. Ramsay to comment on "the folly of women's minds... and now, she flew in the face of facts, made his children hope what was utterly out of the question, in effect, told lies" (31). He feels that women are irrational and uneducated.

Her family thinks Mrs. Ramsay is uneducated when she brings up an issue with milk delivery in London; her family laughs and waves her concerns away when she brings up the subject at dinner:

Speaking with warmth and eloquence, she described the iniquity of the English dairy system, and in what state milk was delivered at the door, and was about to prove her charges, for she had gone into the matter, when all round the table, beginning with Andrew in the middle, like a fire leaping from tuft to tuft of furze, her children laughed; her husband laughed; she was laughed at, fire-encircled, and forced to veil her crest, dismounted her batteries, and only retaliate by displaying the raillery and ridicule of the 
table to Mr. Bankes as an example of what one suffered if one attacked the prejudices of the British People. (Woolf 103)

Mrs. Ramsay knows a great deal on the subject because she visits the people who receive the spoiled milk; she cares for the poor in her community, and her family laughs at her, thinking she knows nothing. Mrs. Ramsay is afraid to learn, to become an equal to her husband: "Books, she thought, grew of themselves. She never had time to read them" (27). Perhaps keeping herself uneducated will make her husband desire her more. This role as mother and nurse is all Mrs. Ramsay knows; she is not trying to change her life, and even encourages the younger generations to marry.

Lily Briscoe watches Mrs. Ramsay throughout the first section of the novel and is infatuated with her. Lily represents the future of womanhood, and for her to become independent, she needs to shed the old views of womanhood and replace it with a new norm. Lily does this through her painting. Ronchetti points out that "Lily's relationship to Mrs. Ramsay is quite complex, compounded as it is of admiration, longing, annoyance, criticalness, and endless fascination" (69). Being an outsider, and literally outside the Ramsay's house, Lily observes the Ramsay family while attempting to paint a picture of Mrs. Ramsay and James through the window. She is unable to finish the painting until, at the end, she no longer idolizes Mrs. Ramsay and what she represents.

Mrs. Ramsay describes Lily at the beginning of the novel: "With her little Chinese eyes and her puckered-up face, she would never marry; one could not take her painting very seriously; she was an independent little creature, and Mrs. Ramsay liked her for it” (Woolf 17). Again, while comparing Lily to Minta Doyle, another guest of Mrs. Ramsay, she thinks, 
She faded, under Minta's glow; became more inconspicuous than ever, in her little grey dress with her little puckered face and her little Chinese eyes. Everything about her was so small. Yet, thought Mrs. Ramsay, comparing her with Minta, as she claimed her help... of the two, Lily at forty will be better. There was in Lily a thread of something; a flare of something; something of her own which Mrs. Ramsay liked very much indeed, but no man would, she feared. (Woolf 104)

Lily is content with remaining out of the center of attention. She takes pride in being an observer, being someone who is emotionally able to remain single; this is how she can create. Minta is following Mrs. Ramsay's guidance by marrying, while Lily pushes against marriage and pursues art. Mrs. Ramsay fears that "an unmarried woman has missed the best of life" (Woolf 49). Daniela Munca, in her article "Virginia Woolf's Answer to 'Women Can't Paint, Women Can't Write' in To the Lighthouse," examines some questions that Lily raises:

What is best in life for a woman: what she chooses or what the society imposes on her because of her gender? Does a woman have to give up her artistic vision in favor of becoming a perfect wife and mother? Does a woman miss the best in life if she chooses not to confront to these prejudices? Her answer is, as nothing is certain in this world, no marriage can promise a sublime happiness; no Victorian moral or standard can actually guarantee happiness. Art, on the other hand, is immune from change, it can capture the essence of those intense moments of vision, it can transcend time and human life, it has the power to satisfy such a restless searching soul as Virginia Woolf's, and Lily Briscoe will help us realize this by the end of the novel. (279) 
In order to complete her painting, Lily must kill her Angel in the House, Mrs. Ramsay. Lily proves that women can do more than marry and raise a family when she completes her painting at the end of the novel.

Ten years after Mrs. Ramsay's death, Lily returns to the summer home and finishes her painting. Before she can do this, she must grieve for Mrs. Ramsay and resolve her conflict with Mr. Ramsay and his emotionally demanding role as patriarch. Ronchetti states, "Art in the form of painting and life in the form of Mrs. Ramsay's psychological legacy to Lily cooperate to stimulate her personal growth as well as her artistic creativity" (69). For Lily, "painting requires the shedding of one's personal traits, ego needs, sexuality, and social role until one has reached the state of impersonality necessary for an aesthetic vision to emerge" (Ronchetti 70). In the first section of the novel, "The Window," Lily struggles with her lack of confidence as an artist. She thinks about her painting, while Mr. Banks looks on and believes,

It was bad, it was bad, it was infinitely bad! She could have done it differently of course; the color could have been thinned and faded... But then she did not see it like that. She saw the colour burning on a framework of steel... And it would never be seen... and there was Mr. Tansley whispering in her ear, 'Women can't paint, women can’t write. (Woolf 48)

Lily does not want her painting to be seen by anyone because she does not feel she has accurately portrayed what it is that she is seeing. Lily is painting from the point of view of a social outcast. Being a single woman of thirty-three, she sees the world differently, and she is afraid the world will not accept her different view.

Lily finishes her painting at forty-four years old after she, as Ronchetti states, "comes to terms with her ambivalent feelings toward Mrs. Ramsay and accepts her [Lily's] relationship 
with her [Mrs. Ramsay] husband" (Ronchetti 75). Lily feels she did not grieve enough after Mrs. Ramsay's death. Memories of the time spent in the house flood her thoughts throughout the morning; she cannot figure out what her feelings are about being in the house without Mrs. Ramsay. Sitting at the empty kitchen, she keeps asking herself:

What does it mean?- a catchword that was, caught up from some book, fitting her thought loosely, for she could not, this first morning with the Ramsays, contract her feelings, could only make a phrase resound to cover the blankness of her mind until these vapours had shrunk. For really, what did she feel, come back after all these years and Mrs. Ramsay dead? Nothing, nothing - nothing that she could express at all. (Woolf 145) Lily has no reason to be there; she has no connection to the house other than Mrs. Ramsay, and she is not there. Lily has trouble filling the role Mrs. Ramsay left; when the remaining family members are trying to get things together to bring on their trip to the lighthouse, Lily cannot think of anything to suggest to Nancy when she asks, "in a queer half dazed, half desperate way, 'What does one send to the Lighthouse?"' (146). Unable to answer, Lily continues her existential crisis, incapable of feeling any emotion about Mrs. Ramsay's death, while avoiding Mr. Ramsay and the sympathy he will demand from her. Ronchetti observes, "it is only until she remembers how Mrs. Ramsay was able to conciliate her momentarily with Tansley that morning on the beach that Lily begins to recall Mrs. Ramsay's formidable skills as a peacemaker and unifier. However, she also recalls Mrs. Ramsay's manipulative behavior and her passion for matchmaking" (75).

Mr. Tansley and Lily had different outlooks on life, but for one moment, Mrs. Ramsay was able to get the two to put their differences aside and create a lasting memory. Lily recalls how Tansley would say to her, “woman can't paint, can't write. Coming up behind her, he had 
stood close beside her, a thing she hated, as she painted here on this very spot. 'Shag tobacco,' he said, 'fivepence an ounce,' parading he poverty, his principles” (Woolf 159). Immediately after this thought, Lily remembers the day on the beach:

It was a windy day. They had all gone down to the beach. Mrs. Ramsay sat down and wrote letters by a rock. She wrote and wrote. 'Oh,' she said, looking up at something floating in the sea, 'is it a lobster pot? Is it an upturned boat?' She was so short-sighted that she could not see, and then Charles Tansley became as nice as he could possibly be. He began playing ducks and drakes... What they said she could not remember, but only she and Charles throwing stones and getting on very well all of a sudden and Mrs. Ramsay watching them. (Woolf 160)

Being able to remember something nice about a man who told her, because she was a woman, she could not paint shows Mrs. Ramsay's social artistry at work. While thinking of this good memory, Lily also thinks of Mrs. Ramsay's matchmaking. Mrs. Ramsay's need for everyone to marry backfires with Minta Doyle and Paul Rayley. Lily reflects on the Rayley marriage:

They were 'in love' no longer; no, he had taken up with another woman, a serious woman, with her hair in a plait and a case in her hand (Minta had described her gratefully, almost admiringly), who went to meetings and shared Paul's views (they had got more and more pronounced) about the taxation of the land values and a capital levy. Far from breaking up the marriage, that alliance had righted it. They were excellent friends. (Woolf 174)

Knowing that the marriage Mrs. Ramsay pushed into existence did not last gives Lily a sense of power over her. Mrs. Ramsay and her insistence to marry backfires with the Rayleys. Lily knew 
that Paul and Minta were not right for each other, and the fact that the marriage failed shows Lily that Mrs. Ramsay was not as powerful as she thought. Lily thinks to herself what she would say to Mrs. Ramsay about the lives she meddled in: "It has all gone against your wishes. They're happy like that; I'm happy like this. Life has changed completely" (Woolf 175). As Ronchetti argues, this reflection on the Rayley's marriage also helps to “drain her [Mrs. Ramsay] of her mythic force as a symbol of maternal power and so humanize her, making her a more manageable presence" (75). Now that Mrs. Ramsay has been made human, Lily can be comfortable remaining unmarried, knowing that she does not want a marriage like the Ramsay's. If Lily had married, she would never have finished her painting.

Mr. Ramsay embodies patriarchal ideals; he feels women should give him sympathy on demand. Lily cannot do this; she ignores and avoids him until he shows her that he is an ordinary person. While she is trying to paint and come to terms with the specter of Mrs. Ramsay in her mind, Mr. Ramsay expects her to react the way any other woman would when he needed attention. Lily does not have the mindset that Mr. Ramsay is looking for; she thinks to herself, she should have known how to deal with it. It was immensely to her discredit, sexually, to stand there dumb. One said—what did one say?-Oh, Mr. Ramsay! Dear Mr. Ramsay! That was what that kind old lady who sketched, Mrs. Beckwith, would have said instantly, and rightly. But, no. They stood there, isolated from the rest of the world. His immense self-pity, his demand for sympathy poured and spread itself in pools at her feet, and all she did, miserable sinner that she was, was to draw her skirts a little closer round her ankles, lest she should get wet. (Woolf 152)

Lily knows what he wants from her, but she cannot give it to him; she believes that his neediness had drained Mrs. Ramsay, leading to her death. Her refusal to give in to his Victorian 
ideals and demands brings them to an understanding. When she comments on his "nice boots," Mr. Ramsay's demeanor changes. All he wanted was to be noticed and to have someone pay attention to him. When he bends to tie her shoe, Lily thinks, Why, at this completely inappropriate moment, when he was stooping over her shoe, should she be so tormented with sympathy for him that, as she stooped too, the blood rushed to her face, and, thinking of her callousness (she had called him a play-actor) she felt her eyes swell and tingle with tears. Thus occupied he seemed to her a figure of infinite pathos. (Woolf 154)

The action of tying Lily's shoe shows Lily that he is only human, not the powerful male figure from her memory. Now that Mr. Ramsay is no longer the dominating god and Mrs. Ramsay no longer the domestic goddess, Lily can finish her painting of Mrs. Ramsay and continue her life as a single woman artist. 


\section{Conclusion}

The idea of the spinster has evolved from the word meaning a woman's profession to one evoking the social position of a woman. Jane Austen created female characters in the spinster position that reflected the opinion of her time while also giving these women more of a choice in their lives. In the nineteenth century, it was frowned upon for a woman to remain single. In Pride and Prejudice and Persuasion, Austen takes the traditional marriage plot and alters it to give women more complexity and choice. Elizabeth insists that marriage should be based on love and understanding, not on financial concerns. The marriages in Pride and Prejudice and Persuasion provide examples for the future. The marriages Austen creates are not just contracts-they are based on affection. Austen also makes clear that women need respect and that they have desires other than money and social status. She insists that women are not as simple-minded as men think.

In Virginia Woolf's Mrs. Dalloway, Miss Kilman represents the old-world view of the spinster as a rejected, bitter woman. Elizabeth Dalloway represents the new woman who has new doors and choices open to her. Woolf sees women, both single and married, as artists. Both Mrs. Dalloway and Mrs. Ramsay are social artists. They teach us to make the best out of our situation in life, to add beauty where there is none, to "decorate the dungeon" (Mrs. Dalloway 77). Social artistry can be as meaningful as physical artistry, even if it is only within the domestic realm. As an actual, physical artist, Lily Briscoe realizes her vision and her independent identity by letting go of her idealization of the maternal Mrs. Ramsay and her traditional view of gender roles and marriage. Woolf's female characters, finally, prove that women are not limited solely to being wife and mother. 
Each author pulled from her own life for inspiration in her writing. Austen herself never married, even when given the opportunity. Hazel Jones explains:

She [Austen] recognized that affection, friendship and respect were fundamental elements of any workable relationship, but discovered for herself that a man who combined the ability to inspire the necessary degree of love and esteem with the essential qualification of a good income was not easily come by. Financial inducements alone were not enough to tempt her into matrimony—she turned down one wealthy suitor in the full knowledge that, at the age of twenty-six and with eligible men in scarce supply, she might never receive another proposal of marriage. (5)

Austen took this experience and transferred it into her writing by insisting her heroines marry for love, not money. Woolf's family played a large part in her novel To the Lighthouse. Ronchetti explains how Woolf's sister, Vanessa, was an artist like Lily, while her mother, Julia Duckworth Stephen, was a figure known for her social artistry, like Mrs. Ramsay and Mrs. Dalloway (62). Woolf's overbearing male characters were also modeled after her father, Leslie Stephen.

Even with over one hundred years separating Woolf and Austen, both women writers fought for women's rights through their writing. As time passed, the spinster character slowly became more socially accepted. Society has taken its time in recognizing that women do not need to marry and become a mother to be a productive part of society. Both Austen and Woolf wrote about their time and the injustices in women's lives within society. Emma Liggins states, "In 1926, just before of the achievement of suffrage for women on equal terms with men in 1928, a Time and Tide journalist welcomed the passing away of 'the political lassitude of the war years' and reminded readers that 'this generation of women has a duty, a duty to its own time, a duty to posterity' to continue with the campaign of equality" (208). To this day, women are still 
fighting for equality. The single women of the past endured ridicule and contempt in order for our generation of single women to thrive. 
Austen, Jane. Emma. Bantam, 2004.

\section{Works Cited}

---. Persuasion, edited by Jillian Beer. Penguin Books, 1998.

---. Pride and Prejudice. Bantam, 2003.

Bailey, Martha. “The Marriage Law of Jane Austen's World.” Persuasions: The Jane Austen Journal On-Line, vol. 36, no. 1, 2015. EBSCOhost, serch.ebscohost.com/login.aspx $?$ direct $=$ true $\& d b=$ mlf $\& A N=2017580821 \&$ site $=$ ehost-live .

Brown, Julia Prewitt. Jane Austen's Novels: Social Change and Literary Form. Harvard University Press, 1979.

Casal, Elvira. "More Distinguished in His Domestic Virtues: Captain Wentworth Comes Home." Persuasions: The Jane Austen Journal, vol. 26, 2004, pp. 146-155. EBSCOhost, serch.ebscohost.com/login.aspx $?$ direct $=$ true $\& d b=$ mlf\&AN=2005581615\&site $=$ ehost-live.

Dabundo, Laura, et al. “The Feminist Critique and Five Styles of Women's Roles in Pride and Prejudice.” Critical Insights: Pride \& Prejudice, Sept. 2011, pp. 39-53. EBSCOhost, ric.idm.oclc.org/login?url=http://search.ebscohost.com/login.aspx?direct=true \&db=lfh\& $\mathrm{AN}=70837333 \&$ site $=$ ehost-live .

Dibert-Himes, Audra. "Elizabeth Dalloway: Virginia Woolf’s Forward Look at Feminism." Virginia Woolf: Emerging Perspectives. Selected Papers from the Third Annual International Conference on Virginia Woolf, edited by Mark Hussey et al., Pace University Press, 1994, pp.224-229. EBSCOhost, ric.idm.oclc.org/login?url=http://search.ebscohost.com/login.aspx?direct $=$ true $\& d b=1$ fh $\&$ $\mathrm{AN}=1994065660$ \&site $=$ ehost-live.

Doan, Laura L. Introduction. Old Maids to Radical Spinsters: Unmarried Women in the Twentieth-Century Novel. University of Illinois Press, 1991. 
Gilbert, Sandra M., and Susan Gubar. The Mad Woman in the Attic: the Woman Writer and the Nineteenth-Century Literary Imagination. Yale University Press, 2006.

Henke, Suzette A. "Mrs. Dalloway: The Communion of Saints." New Feminist Essays on Virginia Woolf, edited by Jane Marcus, University of Nebraska Press, 1981, pp. 125-147. Horn, Dashielle. "Choosing Spinsterhood: Enacting Singleness in Persuasion." Persuasions: The Jane Austen Journal, vol. 38, 2016, pp. 236-244. EBSCOhost, ric.idm.oclc.org/login?url=http://search.ebscohost.com/login.aspx?direct=true \&db=lfh\& AN $=2017581574 \&$ site $=$ ehost-live.

Jones, Hazel. Jane Austen and Marriage. Continuum, 2009.

Kern, Jean B. "The Old Maid; Or, 'To Grow Old, and Be Poor, and Laughed At."” Fetter'd or Free? British Women Novelists, 1670-1815, edited by Mary Anne Schofield and Cecilia Macheski, Ohio University Press, 1986, pp. 201-214.

Liggins, Emma. Odd Women?: Spinsters, Lesbians and Widows in British Women's Fiction, 1850s-1930s. Manchester University Press, 2014.

Lilienfeld, Jane. "Where the Spear Plants Grew: The Ramsay's Marriage in To the Lighthouse." New Feminist Essays on Virginia Woolf, edited by Jane Marcus, University of Nebraska Press, 1981, pp. 148-169.

Magee, William H. “Instrument of Growth: The Courtship and Marriage Plot in Jane Austen's Novels." Journal of Narrative Technique, vol. 17, no. 2, 1987, pp. 198-208. EBSCOhost, search.ebscohost.com/login.aspx?direct=true $\& \mathrm{db}=$ mlf $\& A N=1988021054 \&$ site $=$ ehostlive.

Moe, Melina. "Charlotte and Elizabeth: Multiple Modernities in Jane Austen's Pride and 
Prejudice.” ELH: English Literary History, vol. 83, no. 4, 2016, pp. 1075-

1103. EBSCOhost, search.ebscohost.com/login.aspx?direct=true $\& d b=$ mlf $\& A N=2017580090 \&$ site $=$ ehostlive.

Moon, Kenneth. "Where Is Clarissa? Doris Kilman and Recoil from the Flesh in Virginia Woolf’s Mrs. Dalloway.” CLA Journal, vol. 23, 1980, pp. 273-286. EBSCOhost, search.ebscohost.com/login.aspx?direct=true $\& \mathrm{db}=$ mlf\&AN=1980109698\&site=ehostlive.

Munca, Daniela. “Virginia Woolf's Answer to 'Women Can't Paint, Women Can't Write' in To the Lighthouse.” Journal of International Women's Studies, vol. 10, no. 4, May 2009, pp. 276-289. EBSCOhost, search.ebscohost.com/login.aspx?direct=true $\& \mathrm{db}=\mathrm{mlf} \& \mathrm{AN}=2010026102 \&$ site $=$ ehostlive.

Neubauer, Breanna. "This Old Maid: Jane Austen and Her S(p)i(n)Sters." Midwest Quarterly: A Journal of Contemporary Thought, vol. 56, no. 2, 2015, pp. 124-138. EBSCOhost, search.ebscohost.com/login.aspx?direct=true $\& \mathrm{db}=\mathrm{mlf} \& \mathrm{AN}=2018700773 \&$ site $=$ ehostlive.

Rachman, Shalom. "Clarissa's Attic: Virginia Woolf’s Mrs. Dalloway Reconsidered." Twentieth Century Literature, vol. 18, no. 1, Jan. 1972, pp. 3-18. EBSCOhost, search.ebscohost.com/login.aspx?direct=true $\& \mathrm{db}=\mathrm{mlf} \& \mathrm{AN}=0000108081 \&$ site $=$ ehostlive.

Ronchetti, Ann. The Artist-Figure, Society, and Sexuality in Virginia Woolf's Novels, Routledge, 
2004. ProQuest Ebook Central, https://ebookcentral.proquest.com/lib/ricebooks/detail.action?docID=183019.

Shaffer, Julie. "Not Subordinate: Empowering Women in the Marriage Plot--The Novels of Frances Burney, Maria Edgeworth, and Jane Austen.” Reading with a Difference: Gender, Race, and Cultural Identity, edited by Arthur F. Marotti et al., Wayne State University Press, 1993, pp. 21-43. EBSCOhost, search.ebscohost.com/login.aspx?direct=true \&db=mlf\&AN=1994067975\& site=ehostlive.

Showalter, Elaine. "Killing the Angel in the House: The Autonomy of Women Writers." Antioch Review, vol. 50, no. 1-2, 1992, pp. 207-220. EBSCOhost, doi:10.2307/4612511.

Tyson, Lois. Critical Theory Today: a User-Friendly Guide. Routledge, 2009.

Vranjes, Vlasta. "Jane Austen, Lord Hardwicke's Marriage Act, and the National Courtship Plot." CLIO: A Journal of Literature, History, and the Philosophy of History, vol. 43, no. 2, 2014, pp. 197-223. EBSCOhost, search.ebscohost.com/login.aspx?direct=true $\& \mathrm{db}=$ mlf\&AN=2014395034\&site=ehostlive.

Wallace, Jo-Ann. "Woolf’s 'Spinsters': The Body and the Blank Page of His/Story.” English Studies in Canada, vol. 26, no. 2, June 1990, pp. 201-214. EBSCOhost, search.ebscohost.com/login.aspx?direct=true \&db=mlf\&AN=1990086442\&site=ehostlive.

Wolfe, Jesse. "The Sane Woman in the Attic: Sexuality and Self-Authorship in Mrs. Dalloway." MFS: Modern Fiction Studies, vol. 51, no. 1, 2005, pp. 34-59. EBSCOhost, doi:10.1353/mfs.2005.0018. 
Woolf, Virginia. A Room of Own's Own, edited by Susan Gubar. Harcourt, 2005.

---. To the Lighthouse, edited by Eudora Wetly. Harcourt Brace \& Company, 1981.

---. Mrs. Dalloway. Harcourt, 2002. 